\title{
CATION EXCHANGE RESIN (RESODEC) IN THE TREATMENT OF CARDIAC CEDEMA
}

\author{
BY
}

\author{
A. A. FITZGERALD PEEL AND T. SEMPLE \\ From the Cardiac Department, Victoria Infirmary, Glasgow \\ Received November 16, 1952
}

Cardiac œdema has long been attributed to increased intracapillary pressure secondary to raised venous pressure, but in recent years the role of sodium in the formation of odema has received increasing attention. Peters (1935), Best and Taylor (1937), and Gamble (1937) pointed out that retention of sodium in the tissue spaces promotes the accumulation of water. Brod and Fejfar (1950) suggested that cardiac œdema depends, not on changes in venous pressure, but on renal vasoconstriction with diminished renal blood flow and consequent retention of water and salt. On the other hand, Dock (1949) reported that the rate of odema formation is determined more by sodium ingestion than by reduction of cardiac output and renal blood flow. As a corollary to these concepts there arose the idea of sodium restriction as a therapeutic measure.

In common with other investigators we have had numerous gratifying results from a diet yielding a daily intake of $800 \mathrm{mg}$. sodium in refractory or relapsing congestive failure. Many of our patients had been cedematous and bedridden for periods up to six months prior to dietetic treatment: they have become free from œdema and ambulant, in several instances for as long as three years. In these refractory cases it is necessary to continue sodium restriction indefinitely: several patients have had recurrence of œdema within a few days of relaxing the diet. Cameron (1949) gave salt to patients whose odema had been abolished by digitalis, diuretics, and low sodium diet: 2 grams of salt or sodium bromide daily $(400 \mathrm{mg}$. sodium) caused a significant increase in weight almost immediately. This increment corresponds to a change from a "low sodium diet" to a " salt free diet."

Dietetic sodium restriction has several disadvantages. The food is apt to be savourless. As a domiciliary treatment it requires separate cooking for the patient and it is usually impracticable during holidays. The diet is deficient in chloride as well as in sodium; it necessitates the taking of ammonium chloride or hydrochloric acid, to which some patients object strongly. Finally, if supplementary chloride is not taken in adequate amount, it may cause dangerous sequelæ (Black and Litchfield, 1950), a risk that is intensified when mercurial diuretics are used as well. The disadvantages have stimulated research, notably in America, on the possibility of achieving sodium deprivation by means of ion exchange resins.

Clinical use of ion exchange resins was first suggested by Segal et al. (1945) using anion exchange resins for the control of gastric acidity in peptic ulcer; a year later Dock (1946) gave a cation exchange resin to rats and dogs orally, showing that it was non-toxic and that it increased the fæcal excretion of sodium. Two main groups of resins have been tried clinically-sulphonic resins by Kahn and Emerson (1950), MacIntyre and Jordan (1951), Morton (1951) and Friedman et al. (1951); carboxylic resins by Cobbey et al. (1949), Kahn and Emerson (1950), Chapman and Pannill (1950), Martz et al. (1950), Zatuchni (1951) and Kleiber and Pickar (1951). The earlier resins exchanged hydrogen ions for sodium and potassium; they occasionally produced hypokalæmia. Combined ammonium and potassium resins were accordingly introduced; these have 20 per cent of their hydrogen ions replaced by potassium and 80 per cent by ammonium. In the acid gastric contents they exchange 
ammonium and potassium for hydrogen ions. The potassium compensates for that absorbed in the alkaline contents of the intestinal tract: here the resin exchanges hydrogen for sodium, potassium, and calcium ions which are excreted with it in the fæces. The use of combined ammonium and potassium resin in cardiac odema has been reported by Irwin et al. (1949), Hay and Wood (1950), Dock and Frank (1950), Chapman and Pannill (1950), McChesney (1950), Flannagan et al. (1951) and Lefken et al. (1951). In patients with impaired renal function, ammonium chloride liberated in the stomach may give rise to acidosis, but apart from this few serious side effects were observed; the resin was considered to be of value in congestive heart failure and in cirrhosis of the liver.

\section{MATERIAL AND MethodS}

The therapeutic trial was made with a balanced ammonium-potassium form of carboxylic cation exchange resin (resodec). As subjects we chose ten patients with refractory or recurring congestive heart failure. Seven had been on treatment with low sodium diet for periods varying from several weeks up to two years; their individual clinical and biochemical response to variations in the sodium content of the diet was well known to us. Prior to dietetic treatment they had either failed to respond to routine digitalis and mercurial diuretic treatment: or odema had recurred on withdrawal of mercurials or when the patient was allowed up. The diet had a calculated sodium content of $700 \mathrm{mg}$. daily, but analysis on several occasions showed an average sodium content of $800 \mathrm{mg}$. Supplementary chloride was given as ammonium chloride (45 to 60 gr. daily) or as dilute hydrochloric acid (10.6 c.c. daily), the dosage being varied in accordance with the plasma chloride level. Four of the seven became odema-free and ambulant, remaining so for as long as they adhered to the diet; but œdema returned whenever they took ordinary diet. Three of them were treated with resodec when they next developed œdema; the fourth was given increasing doses of salt until he developed œdema and was then given resodec. Two other cases were responding slowly to diet when resodec was given with the object of accelerating the loss of ædema. In the seventh patient, œdema could be reduced but not abolished by diet; resodec was used in addition to the diet. Three other patients who would ordinarily have been selected for dietetic treatment were instead given resodec.

The dosage of resodec was $45 \mathrm{~g}$. daily in three doses, except in one case where varying doses were tried; $30 \mathrm{~g}$. daily produced no improvement while $60 \mathrm{~g}$. gave no better result than $45 \mathrm{~g}$. and was less well tolerated, a finding that agrees with the experience of previous observers. The resin was given in tea, fruit juice, or milk. Additional calcium was provided, in one case as calcium gluconate and in the remainder as extra milk. Fluids were not restricted. Weight, urinary output and urinary chlorides were recorded daily, but the weight records covering four courses of treatment are not available; blood electrolytes were estimated weekly in all cases, twice weekly in some. In one patient sodium balance experiments were carried out and in two others the urinary excretion of sodium was estimated.

The ten patients between them received fourteen courses of resodec treatment, varying in duration from 3 to 18 days. In nine instances the resodec was given with ordinary ward diet, as a substitute for low sodium diet; in five it was used as a supplement to low sodium diet with a view to producing a greater degree of sodium restriction.

\section{RESULTS}

We would emphasize at the outset that we deliberately chose patients who had previously proved refractory to routine digitalis and mercurial diuretics. Table I gives the clinical result of fourteen courses of resodec treatment in such cases, compared with the effect of previous dietetic sodium restriction when known.

Weight and redema. Body weight was reduced in nine of the ten cases in which weight records were available and presumably in two of the remaining four. The reduction amounted to $0.9 \mathrm{~kg}$. daily in one case, $0.67 \mathrm{~kg}$. daily in one, and approximately $0.45 \mathrm{~kg}$. daily in four. Edema was abolished in four, lessened 
in seven, and unchanged in three. Case 1 , who gained $4.5 \mathrm{~kg}$. in 21 days with low sodium diet plus added salt, lost the same amount in $\mathbf{1 0}$ days on ward diet plus resodec. Case 3 had gross odema which failed to clear after several weeks' treatment with digitalis and mersalyl; low sodium diet reduced the bulk of her œdema and ascites but there remained œdema of the thighs which began to increase slowly when she was allowed up. Her minimum weight on low sodium diet was $57.6 \mathrm{~kg}$; when given resodec as a supplement to low sodium diet, her œedema was reduced to an insignificant trace and her weight fell to $52.2 \mathrm{~kg}$. in 9 days. On withholding resodec her weight rose and oedema returned. She was given two more short courses of resodec while in hospital, on each occasion with loss of weight and reduction of œdema. For the next nine months she kept herself ambulant by continuing the diet and taking resodec for three days at a time whenever her weight rose to $54.9 \mathrm{~kg}$.; she died while on holiday some 200 miles from home.

TABLE I

Clunical Effects and Side-effects of Resodec

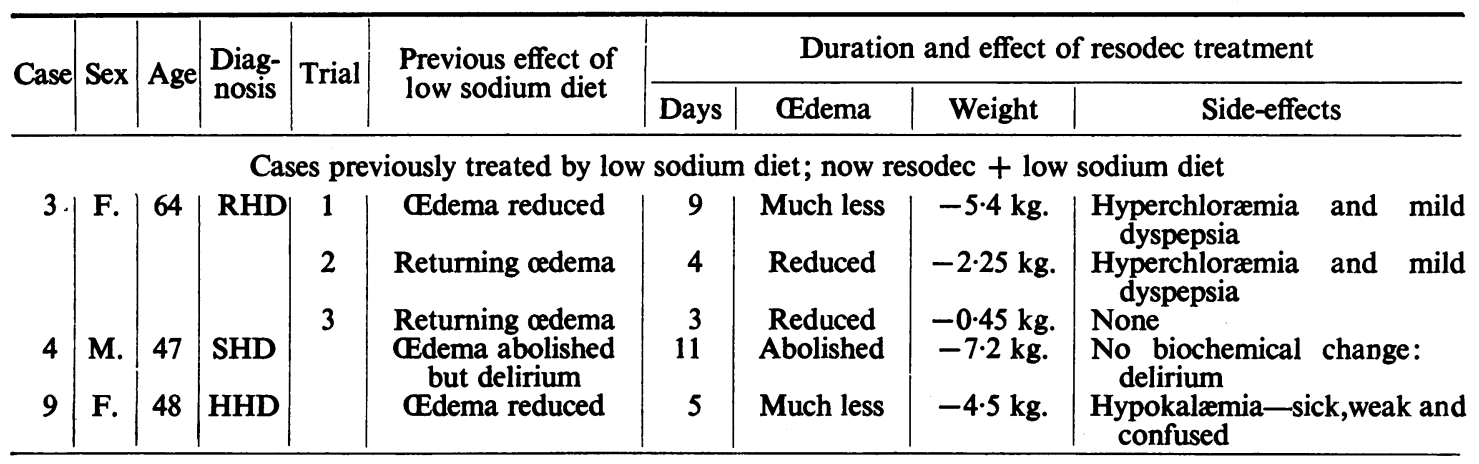

Cases previously treated by low sodium diet; now resodec + ordinary ward diet

\begin{tabular}{|c|c|c|c|c|c|c|c|c|c|}
\hline & M. & $\begin{array}{l}64 \\
41\end{array}$ & $\mid \begin{array}{l}\text { HHD } \\
\text { RHD }\end{array}$ & & $\begin{array}{l}\text { Edema abolished } \\
\text { CEdema reduced }\end{array}$ & $\begin{array}{l}10 \\
18\end{array}$ & $\begin{array}{l}\text { Abolished } \\
\text { Reduced }\end{array}$ & $\begin{array}{l}-4.5 \mathrm{~kg} . \\
-1.35 \mathrm{~kg}\end{array}$ & $\begin{array}{l}\text { Hyperchloræmia, acidosis } \\
\text { Mild hyperkalæmia and }\end{array}$ \\
\hline 6 & F. & 63 & HHD & & $\begin{array}{l}\text { Edema slowly } \\
\text { reduced }\end{array}$ & 12 & Abolished & $-5.4 \mathrm{~kg}$ & $\begin{array}{l}\text { Hyperkalæmia, hyponatræ- } \\
\text { mia, transient diarrhœa and } \\
\text { vomiting }\end{array}$ \\
\hline 8 & M. & 57 & RHD & 2 & $\begin{array}{c}\text { Abolished } \\
\text { Returning œdema }\end{array}$ & $\begin{array}{l}10 \\
11\end{array}$ & $\begin{array}{l}\text { Abolished } \\
\text { Unchanged }\end{array}$ & $\begin{array}{c}-1.35 \mathrm{~kg} . \\
-\end{array}$ & $\begin{array}{l}\text { None from resin; digitalis } \\
\text { intoxication } \\
\text { None from resin; no improve- } \\
\text { ment. Died 11th day }\end{array}$ \\
\hline
\end{tabular}

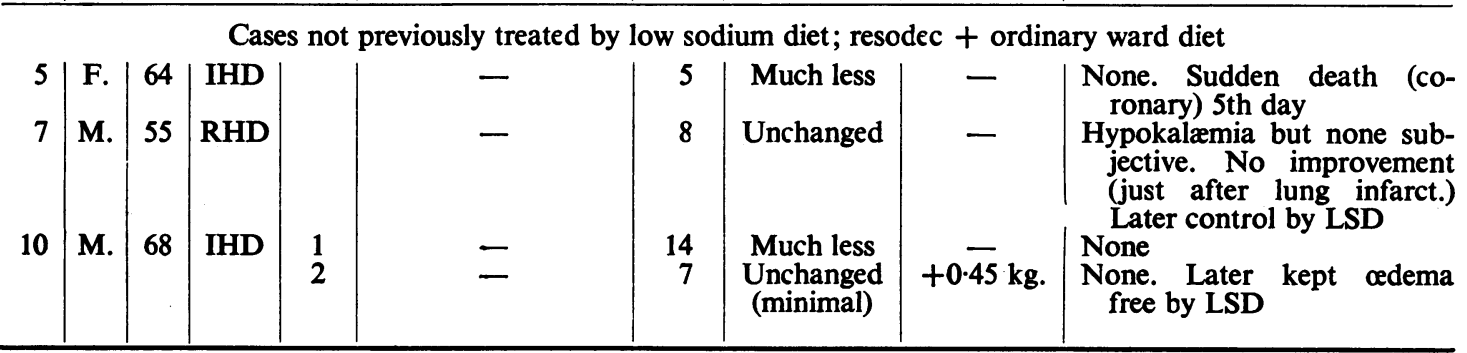

LSD = Diet containing $800 \mathrm{mg}$. sodium daily with $45-60 \mathrm{gr}$. $\mathrm{NH}_{4} \mathrm{Cl}$.

RHD $=$ Rheumatic heart disease.

SHD $=$ Syphilitic heart disease.

HHD $=$ Hypertensive heart disease.

IHD = Ischæmic heart disease.

Urine. A reduction in weight and œedema brought about by resodec was not necessarily accompanied by diuresis. The average daily output remained unchanged during eight courses of treatment, in seven of which weight was lost and œedema lessened. This is contrary to our experience with dietetic sodium restriction which usually produces a dècided diuresis. Mild diarrhœa occurred in one of these cases and vomiting may explain the absence of diuresis in a second; but four patients lost weight and odema without diuresis, diarrhœea, or vomiting. Nevertheless the gastro-intestinal tract seems the most likely route of the fluid loss. 
Urinary sodium excretion was estimated in two patients before and during resodec treatment. Case 1, who lost $4.5 \mathrm{~kg}$. in weight, showed a progressive rise in sodium excretion from 113 to 211 milli-equivalents per day while on resodec. Case 2 lost $2 \cdot 2 \mathrm{~kg}$. in weight and her sodium excretion rose from 54 to $88 \mathrm{~m}$-eq. per day during the first three days on resodec; during the next three days sodium excretion fell to 58 m-eq. per day and weight increased $0.9 \mathrm{~kg}$. though treatment was unchanged. On increasing the dose of resodec to $60 \mathrm{~g}$. daily the sodium excretion dropped still further, to $39 \mathrm{~m}$-eq. per day and weight rose another $0.45 \mathrm{~kg}$. Case 6, who lost $5.4 \mathrm{~kg}$. in weight excreted $96 \mathrm{~m}$-eq. daily for the first three days and $88 \mathrm{~m}$-eq. daily for the second three days as compared with $61 \mathrm{~m}$-eq. daily during a subsequent period of dietetic sodium restriction. These findings suggest that urinary sodium excretion rises during periods of weight reduction in response to resodec, but may fall when weight reduction ceases or is reversed.

The urinary chloride excretion increased when resodec produced loss of weight and diminution of œdema. An appreciable fall in chloride excretion occurred in two patients in whom resodec failed to lower weight or reduce odema. The explanation offered is that the resin absorbs sodium from the sodium chloride of the diet leaving the chloride to be absorbed by the patient, presumably in the form of its ammonium salt. This will increase the urinary chloride excretion unless the chloride is fixed by sodium in the tissues, in which case œdema will persist or increase. A considerable rise in urinary chloride excretion is sometimes insufficient to prevent hyperchloræmia.

Plasma chloride. Figures for the plasma chloride level before and after treatment are available for 11 courses. The final plasma chloride level was higher than the initial level in 9 instances (Table II), while

TABLE II

EFfect of Resodec on BLOOd Electrolytes

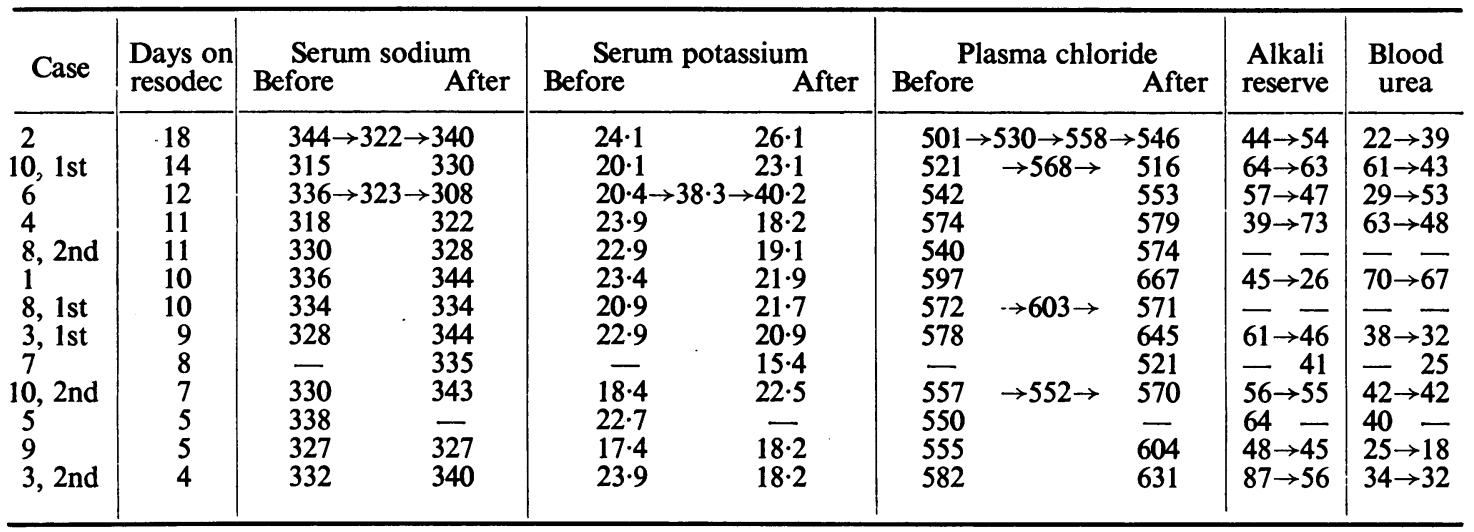

Case 5 died suddenly (coronary disease) before second blood sample was taken. No blood sample available before start of treatment in Case 7.

Figures expressed in mg. per $100 \mathrm{ml}$. Alkali reserve in vols. $\mathrm{CO}_{2}$ per $100 \mathrm{ml}$.

in the remaining two there was an initial rise followed by a fall. In four cases the initial plasma chloride level was low $(501,521,540$, and $542 \mathrm{mg}$. per $100 \mathrm{ml}$.) in consequence of previous low sodium diet or mersalyl: the rise during resodec administration brought these cases within or near the normal range. On three occasions hyperchloræmic levels were reached $(631$ to $667 \mathrm{mg}$. per $100 \mathrm{ml}$.): the highest of these values was assoicated with a drop in $\mathrm{CO}_{2}$ combining power from 45 to 26 vols. per $100 \mathrm{ml}$.

The effect of resodec on plasma chloride is the reverse of that of low sodium diet. Dietary sodium occurs mainly in the form of chloride and bicarbonate; a diet poor in sodium is also deficient in chloride. One of the main problems with low sodium diet is to prevent a fall in plasma chloride which may precipitate an Addisonian crisis with hypotonia, asthenia, mental symptoms, and even death. It is likely that patients whose plasma chloride level cannot be adequately maintained on low sodium diet will prove amenable to resin therapy, while those who become hyperchloræmic with resin therapy will respond better to diet. We have not had an opportunity of testing the former thesis, but have had success with low sodium diet in a case of the latter type.

Serum sodium. Table II gives the serum sodium levels before and after treatment in 11 courses. In eight the serum sodium was within the normal range both before and after treatment; the figure rose 2B 
slightly in four cases, fell slightly in one, and remained stationary in three. Two patients had subnormal serum sodium before treatment, with normal values at the end of the course. In one patient the level fell from normal $(336 \mathrm{mg}$. per $100 \mathrm{ml}$.) to a hyponatræmic value $(308 \mathrm{mg}$. per $100 \mathrm{ml})$; the serum potassium rose simultaneously from 20 to $40 \mathrm{mg}$. per $100 \mathrm{ml}$; the patient had transient diarrhœa and vomiting; normal values were regained within two days of stopping the resin treatment and a tendency for œdema to recur was easily controlled by low sodium diet.

Serum potassium. In seven patients (six of whom had previously been on low sodium diet) the serum potassium was slightly elevated before starting resodec therapy. In five of these the level fell during administration of the resin and was normal at the end of treatment. One with coronary disease died suddenly before the second blood sample was obtained. In the seventh the level continued to rise from 24 to $26 \mathrm{mg}$. per $100 \mathrm{ml}$; the blood urea rose simultaneously from 22 to $39 \mathrm{mg}$. per $100 \mathrm{ml}$., and the rising serum potassium may have been a manifestation of incipient renal decompensation. In four instances the initial serum potassium was normal; one remained normal, two rose to levels just beyond the normal range without any rise in blood urea, and one became doubled, rising from 20 to $38 \mathrm{mg}$. per $100 \mathrm{ml}$. in 7 days and to $40 \mathrm{mg}$. per $100 \mathrm{ml}$. on the 12th day; the blood urea rose from 29 to $53 \mathrm{mg}$. per $100 \mathrm{ml}$. This was a case of hypertensive heart failure in which renal function was known to be defective. Two days after withdrawal of the resin the blood potassium was 18 and blood urea $46 \mathrm{mg}$. per $100 \mathrm{ml}$. After another 3 days she was given $30 \mathrm{~g}$. of resodec in two doses; on the following day her serum potassium was $30.7 \mathrm{mg}$. per $100 \mathrm{ml}$. and nausea recurred. In one patient the initial serum potassium level was slightly subnormal; hypokalæmic symptoms appeared as soon as the resin was given though the serum potassium level was virtually unchanged at the end of the period of treatment. Finally, a patient whose serum potassium was not estimated prior to treatment was found to have a symptomless hypokalæmia with $15.4 \mathrm{mg}$. potassium per $100 \mathrm{ml}$. on the eighth day.

Sodium balance. This was estimated in Case 1 over a period of 56 days during which differing regimes were tried (Table III). He had already been on low sodium diet, without supplementary chloride, for 15 days when the investigation began. For the first 5 days urinary sodium excretion was slowly rising and he was in negative sodium balance. Addition of hydrochloric acid increased the sodium output; for the next 8 days the urinary sodium loss was double the intake. Hydrochloric acid was now replaced by sodium chloride, $2 \mathrm{~g}$. daily for 7 days, $3 \mathrm{~g}$. daily for 10 days, and $4 \mathrm{~g}$. daily for 5 days. Addition of $2 \mathrm{~g}$. of salt daily raised intake and excretion equally; the patient remained in negative balance but to a less extent than before and his weight increased from $64 \cdot 8 \mathrm{~kg}$. to $66.6 \mathrm{~kg}$. With $3 \mathrm{~g}$. daily the sodium excretion fell slightly and he went into positive sodium balance. With $4 \mathrm{~g}$. daily the excretion rose a little, but not sufficiently to balance the increased intake which now exceeded output by one-sixth. Ward diet was next given with unrestricted salt; the exact sodium intake is not known but it was certainly greater than with low sodium diet plus $4 \mathrm{~g}$. added salt: although sodium excretion rose the weight also increased. Resodec was now started. After an initial drop on the first day the sodium excretion rose steadily from 113 to $211 \mathrm{~m}$-eq. per day; negative sodium balance was re-established and was accompanied by a drop in weight from $68.4 \mathrm{~kg}$. to $63.9 \mathrm{~kg}$. and disappearance of the œdema which had developed during the "added salt regime." The serum sodium changed but little during resodec administration; but plasma chlorides rose from 597 to 667 $\mathrm{mg}$. per $100 \mathrm{ml}$. and the associated acidosis necessitated cessation of resodec treatment. Resumption of low sodium diet reduced the sodium intake by at least 75 per cent, but sodium excretion only fell 25 per cent so that negative sodium balance persisted.

These results lend support to the view that the kidney in congestive failure is unable to maintain sodium balance when the sodium intake exceeds a certain critical level -in this patient between 70 and 105 m-eq. (1600 and $2400 \mathrm{mg}$.) per day. Although the kidney is capable of achieving a vastly higher output of sodium per day (as seen during the last 3 days of resodec administration), the excretion does not rise proportionately to the intake, and negative balance can only be obtained when the intake is cut down.

\section{SIDE-EFFECTS}

Undesirable side-effects appeared in half the cases.

Hyperchloramia occurred on three occasions, twice in one patient accompanied by mild dyspepsia and gastric acidity, once in another case when it caused more severe dyspepsia, anorexia, irritability, depression and a serious fall in $\mathrm{CO}_{2}$ combining power of the blood. The former patient was having resodec in addition to low sodium diet and was still receiving supplementary ammonium chloride which probably accounts for her acidosis. The other patient was on ward diet without supplementary ammonium chloride; he had defective renal function. 
TABLE III

Sodium Intake, Urinary Sodium Excretion, Serum Sodium and Weight in Case 1 on Differing Regimes

\begin{tabular}{|c|c|c|c|c|c|}
\hline Period & Regime & $\begin{array}{c}\text { Sodium } \\
\text { intake } \\
\text { (m-equiv./day) }\end{array}$ & $\begin{array}{c}\text { Urinary } \\
\text { sodium } \\
\text { (m-equiv./day) }\end{array}$ & $\begin{array}{c}\text { Serum } \\
\text { sodium } \\
\text { mg./100 ml.) }\end{array}$ & Weight in $\mathrm{kg}$. \\
\hline $\begin{array}{l}\text { Dec. } 1 \\
\text { to } 5\end{array}$ & $\begin{array}{l}\text { Low sodium diet } \\
\text { No extra chloride }\end{array}$ & 35 & 56 & 340 & $64 \cdot 3 \rightarrow 65 \cdot 2$ \\
\hline $\begin{array}{r}\text { Dec. } 10 \\
\text { to } 18\end{array}$ & $\begin{array}{l}\text { Low sodium diet } \\
+3 \text { drams } \mathrm{HCl}\end{array}$ & 35 & 74 & $\begin{array}{l}337 \\
330\end{array}$ & $63 \cdot 9 \rightarrow 64 \cdot 8$ \\
\hline $\begin{array}{r}\text { Dec. } 19 \\
\text { to } 25\end{array}$ & $\begin{array}{l}\text { Low sodium diet } \\
+2 \text { grams } \mathrm{NaCl}\end{array}$ & 70 & 110 & 344 & $64 \cdot 8 \rightarrow 66 \cdot 6$ \\
\hline $\begin{array}{l}\text { Dec. } 26 \\
\text { to Jan. } 4\end{array}$ & $\begin{array}{l}\text { Low sodium diet } \\
+3 \text { grams } \mathrm{NaCl}\end{array}$ & 105 & 100 & 336 & $66 \cdot 6 \rightarrow 66 \cdot 5$ \\
\hline $\begin{array}{r}\text { Jan. } 5 \\
\text { to } 9\end{array}$ & $\begin{array}{l}\text { Low sodium diet } \\
+4 \text { grams } \mathrm{NaC} 1\end{array}$ & 140 & 119 & & $66 \cdot 1 \rightarrow 67 \cdot 0$ \\
\hline $\begin{array}{r}\text { Jan. } 10 \\
\text { to } 12\end{array}$ & $\begin{array}{l}\text { Ward diet } \\
\text { Salt ad lib }\end{array}$ & Over 140 & 147 & & $66 \cdot 6 \rightarrow 68 \cdot 0$ \\
\hline Jan. 13 & $\begin{array}{l}\text { Ward diet, salt ad lib } \\
+ \text { Resodec } 45 \text { grams }\end{array}$ & Over 140 & 113 & & $68 \cdot 4$ \\
\hline $\begin{array}{r}\text { Jan. } 14 \\
\text { to } 16\end{array}$ & do. & Over 140 & 142 & & $68 \cdot 4 \rightarrow 68 \cdot 0$ \\
\hline $\begin{array}{r}\text { Jan. } 17 \\
\text { to } 19 \\
\end{array}$ & do. & Over 140 & 193 & 344 & $68 \cdot 0 \rightarrow 66 \cdot 6$ \\
\hline $\begin{array}{r}\text { Jan. } 20 \\
\text { to } 22 \\
\end{array}$ & do. & Over 140 & 211 & & $66 \cdot 6 \rightarrow 63 \cdot 9$ \\
\hline $\begin{array}{r}\text { Jan. } 23 \\
\text { to } 25\end{array}$ & $\begin{array}{l}\text { Low sodium diet } \\
\text { No extra chloride }\end{array}$ & 35 & 153 & 366 & $63 \cdot 9 \rightarrow 64 \cdot 3$ \\
\hline
\end{tabular}

Hyperkalamia developed in two patients. One with a serum potassium level of $26 \mathrm{mg}$. per $100 \mathrm{ml}$. had mild diarrhœe, vague abdominal discomfort, irritability and petulance; she refused to continue treatment. In the second case a serum potassium level of 38, rising later to $40 \mathrm{mg}$. per $100 \mathrm{ml}$. was accompanied by transient diarrhœa, nausea, vomiting and hyponatræmia. Both these patients had previously been on low sodium diet but were having ward diet during resin administration.

Hypokalamia occurred twice. One patient who was on low sodium diet plus resodec and whose serum potassium was $17.4 \mathrm{mg}$. per $100 \mathrm{ml}$. on the first day of treatment, became sick, weak, mentally confused, and incontinent of urine. A symptomless hypokalæmia with $15.4 \mathrm{mg}$. potassium per $100 \mathrm{ml}$. was found in the second patient after 8 days' treatment with resodec and ward diet.

Digitalis intoxication appeared in one patient, an occurrence noted also by previous authors.

Finally, one patient became delirious when originally rendered œedema-free by low sodium diet, and delirium recurred when treated by resodec for return of œdema; the delirium could not be correlated with any biochemical change and was attributed to left heart failure. Apart from the more serious side-effects of the resin, most of our patients have complained that it leaves a lingering sticky feeling on their lips, tongue, and palate; and many of them have preferred the dietetic regime to the resin.

\section{SummaRY AND CONClusions}

The effects of " resodec" (a balanced ammonium-potassium carboxylic resin) on 10 patients with congestive heart failure have been studied clinically and biochemically during fourteen courses of treatment.

The resin produces clinical results similar to those of dietetic sodium restriction but sometimes 
with undesirable side-effects which are in the main due to hyperchloræmia or to development of abnormal serum potassium levels.

Biochemical control is essential in the early stages of treatment. This is especially important in patients with renal impairment and in those who have been on sodium restricted diet or on mercurial diuretics; such patients may have abnormal blood electrolyte levels resulting from previous treatment. These abnormalities are sometimes corrected but sometimes aggravated by resin therapy.

Subject to biochemical control, the resin can be used as a substitute for low sodium diet or in conjunction with the diet to reinforce the latter. When given in addition to low sodium diet, the best result was obtained with repeated short courses. Ammonium chloride should be discontinued during periods of resin administration.

The wide variations in the behaviour of serum potassium during resin administration suggest the desirability of having two or more resins with differing potassium contents, suitable for administration either with a rising or a falling serum potassium level; it is hoped to investigate this possibility when suitable patients present themselves.

Low sodium diet tends to produce hypochloræmia: resin therapy tends towards hyperchloræmia. Patients intolerant to one of these forms of treatment may prove ideal for the other.

Our especial thanks are due to Messrs Smith, Kline, and French for ample supplies of resodec: to Dr. Ian Anderson and his staff of the Biochemical Laboratory for their numerous and painstaking estimations of blood and urinary electrolytes and for analysis of diets; to Drs. J. J. McCall, C. McNaughton, A. K. Bain, and R. I. Alexander, Registrar and Resident House Physicians for their general help and supervision of patients; and to Sisters Fraser, Coats, and Harrower for their co-operation throughout the investigations.

\section{REFERENCES}

Best, C. H., and Taylor, N. B. (1937). The Physiological Basis of Medical Practice. Wm. Wood, Baltimore. Black, A. B., and Litchfield, J. A. (1950). Brit. Heart J., 12, 205.

Brod, J., and Fejfar, Z. (1950). Quart. J. Med., 19, 187 and 221.

Cameron, D. R. (1950). Brit. Heart J., 12, 205.

Chapman, D. W., and Pannill, C. H. (1950). Proc. Central Soc. Clin. Res., 23, 20.

Cobbey, T. S. Jr., Williams, R. H., MacRae, N., and Towery, B. T. (1949). Federation Proc., 8 (1), 352.

Dock, W. (1946). Tr. Assoc. Amer. Physicians, 52, 282.

and Frank, N. R. (1950). Amer. Heart J., 40, 638.

Flannagan, T. L., Sax, M. F., and Heming, A. E. (1951). Federation Proc., 10, 295.

Friedman, I. S., Zuckerman, S., and Cohn, T. D. (1951). Amer. J. med. Sci., 221 (6), 672.

Gamble, J. L. (1937). Bull. Johns Hopk. Hosp., 61, 151.

Hay, S. H., and Wood, J. E. Jr. (1950). Ann. intern. Med., 33, 1139.

Irwin, L., Berger, E. V., Rosenburg, V., and Jockenthal, R. (1949). J. Clin. Invest., $28,1403$.

Kahn, S. S., and Emerson, K. Jr. (1950). Amer. Soc. Clin. Invest. Program. 42nd. annual meeting, p. 37.

Kleiber, E. S., and Pickar, G. (1951). Ann. intern. Med., 34, 407.

Lefken, E. B., Hawley, D. K., and Iglauer, A. (1951). Proc. Nat. Mtg. Am. Fed. Clin. Res., Atlantic City, 1951.

McChesney, E. W. (1950). Proprietary Assoc. Meeting Minutes, Dec., 1950, p. 18.

MacIntrye, I., and Jordan, A. (1951). Lancet, 1, 965.

Martz, B. L., Kohlstaedt, K. G., and Helmer, O. M. (1950). Proc. Central Soc. Clin. Res., $23,70$.

Morton, F. (1951). Lancet, 1, 1074.

Peters, J. P. (1935). Body Water. C. C. Thomas \& Co., Baltimore.

Segal, H. L., Hodge, H., Watson, J. S., and Scott, W. J. M. (1945). Gastro-enterology, 4, 484.

Zatuchni, J. (1951). American Practitioner and Digest of Treatment, 2 (2), p. 176. 